\section{UK government concedes to critics of education bill}

\section{- Baker backs down after fierce attacks}

\section{- British academics' lobbying pays off}

\section{London}

FACED with mounting hostility from its own supporters, the British government last week waved the white flag and pledged to amend its proposals on the financing and management of higher education, set down in the Education Reform Bill. Objections have centred around clauses in the bill that would empower the Secretary of State for Education and Science to interfere with the administration of individual institutions. The government had clearly not anticipated the ferocity of the attacks on the bill from the university sector and its own backbench Members of Parliament. University vice-chancellors, whose orchestrated campaign of lobbying seems to have paid off (in spite of its slowness to get off the ground), are reserving final judgement on the government's new stance until specific details of the amendments are tabled.

Announcing the government's climbdown, Mr Kenneth Baker, Secretary of State for Education and Science, told the House of Commons standing committee that is considering the bill that much of the criticism had been "both misguided and misleading, imputing to the government all manner of sinister motives which it simply does not have".

The bill proposes to replace the existing University Grants Committee (UGC) with a Universities Funding Council (a similar 'Polytechnics and Colleges Funding Council' will also be set up), which would be able to attach conditions to any payment it made to an institution. Any institution that failed to comply with the conditions could be required to repay any sums received from the council, with interest. Furthermore, the bill would enable the secretary of state to attach strings to any grants he made to the funding councils. The bill does not make clear whether the funding councils' powers of direction over institutions would apply to sums received from non-government sources.

Baker has promised to bring forward amendments at a later stage of the bill's passage through parliament that will:

- make explicit that funding councils could attach conditions only to funds received from the councils;

- make clear that the secretary of state would not be able to impose specific conditions in relation to the flow of money to particular institutions;
- make any direction to the funding councils by the secretrary of state subject to negative resolution by both houses of parliament;

- empower funding concils to give advice to the government;

- qualify the secretary of state's power to confer additional functions on the funding councils;

- clarify the power of the funding councils to seek repayment of funds not used in accordance with a particular condition.

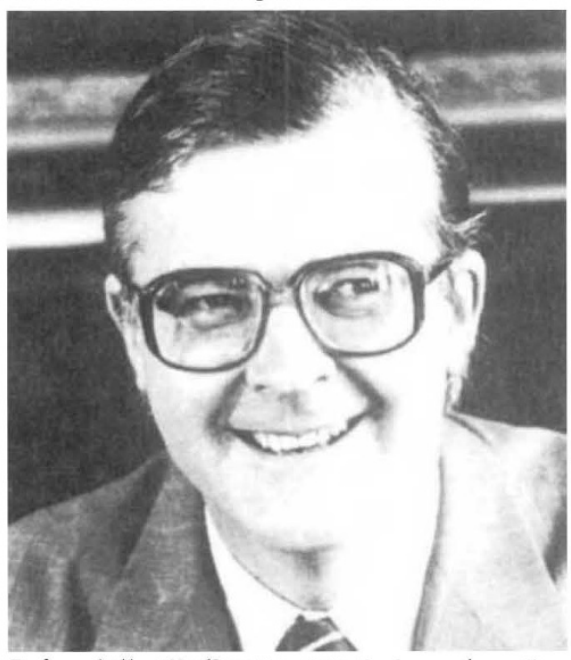

Baker: bill will allow "greater independence".

Professor Sir Mark Richmond, chairman of the Committee of Vice-Chancellors and Principals, cautiously welcomed Baker's announcement as a "step in the right direction". The Association of University Teachers (AUT) was similarly thankful for the government's "surprise concessions". Throughout the controversy over the offending clauses, Baker has insisted that the secretary of state's powers of direction over the funding councils would be used only as a last resort, and that theoretically the education secretary at present has unlimited powers over the UGC. "The only change is that it is now set down in black and white for all to see", he told the standing committee last week.

The education spokesman for the Liberal Party, Mr Paddy Ashdown, contended that legislation spelling out the education secretary's powers would erode the powerful convention that at present effectively forbids him to direct the UGC. In response to government claims that statutory powers of direction under the Science and Technology Act of 1965 exist in relation to the research councils but

\section{Livermore lab head}

JoHN Nuckolls has been named as the new director of Lawrence Livermore National Laboratory (LLNL), to succeed Roger Batzel, who will step down on 3 April after directing the laboratory for more than 16 years.

Nuckolls' selection is seen by some as a victory for supporters of the Strategic Defense Initiative (SDI). Physicist Edward Teller, a strong proponent of SDI, is said to have lobbied hard for his selection.

Although he was Teller's choice, Nuckolls is expected to be a stronger leader than Batzel, leaving individuals like Teller little opportunity to express their personal views as those of the laboratory. Nuckolls is known to be a strong supporter of new weapons technology, but his colleagues nevertheless expect him to be objective and realistic in his role as scientific adviser to Washington policy-makers.

Sidney Drell, co-director of the Center for International Security and Arms Control at Stanford University, praises Nuckolls as "a fine scientist", whose scientific perspective and intelligence should make him a balanced leader. "I would not label him as an ideologue", said Drell.

\section{TV satellite failure}

ThE West German Minister for Telecommunications said in Bonn this week that there "is almost no hope" of saving the TV-SAT direct-broadcasting satellite plagued by a failed solar panel (see Nature 331,$200 ; 1988$ ). The satellite would have marked Europe's entry into direct satellite television broadcasting. Its failure is a bitter disappointment to the German Bundespost, exacerbated by the jubilation surrounding its launch on the Ariane rocket that confirmed resumption of Europe's commercial space industry last November. If West Germany does decide to abandon efforts to save the satellite, only DM95 million of its DM390 million cost will be recovered from the insurers. P.C.

have never been used, Ashdown quoted from a letter written by Sir John Kingman, a former chairman of the Science and Engineering Research Council (SERC), to Sir David Hancock, permanent secretary at the Department of Education and Science (DES).

Although conceding that during his term of office he never received formal direction, Kingman says he did receive "frequent instruction and requests from DES officials. Had I not complied with these I would have been in breach of the act or of the SERC charter, or (as I was often reminded) liable to receive formal direction under the act. The power of direction, like the nuclear deterrent, is no less effective for remaining unused."

Simon Hadlington 